\title{
Effectiveness of Self-selected Teams: A Systems Development Project Experience
}

\author{
Elsje Scott and Michael Pollock \\ University of Cape Town, Cape Town, South-Africa
}

escott@commerce.uct.ac.za mpollock@commerce.uct.ac.za

\begin{abstract}
The third year systems development group project forms an essential part of the Information Systems major at the University of Cape Town. The field of Information Technology / Information Systems requires the maintenance or development of large information systems which often involves complex tasks. As effective teams are at the core of high performance organizations exposure to teamwork is important in the preparation of students for the real world environment. To ensure high quality products and limit high failure rates of projects, teams should be carefully selected. This paper explores existing team selection approaches and discusses the mechanisms put in place in the systems development group project with the emphasis on self-selected teams as a sound base for team formation. It further reports on the incorporation of the criteria defining effectiveness and effective teams into the course to prepare individual members for the rigours of industry.
\end{abstract}

Keywords: Group projects, self-selected, effectiveness, productivity, student enjoyment, performance, skills.

\section{Introduction}

The challenges of a fast-changing and competitive environment compel organizations across all business sectors to be pro-active and adapt. In many cases team-working has been introduced to cope effectively with these changes (Partington \& Harris, 1999). Teams in the workplace not only have a profound effect on productivity, but also make organizations more responsive and have several intrinsic benefits for both the employees and customers (HR Focus, 2002; Katzenbach \& Smith, 1993). According to Katzenbach \& Smith (1993) "teams will become the primary unit of performance in high-performance organizations”.

The field of Information Systems (IS) is heavily reliant on teamwork to improve the quality of information systems (Jones \& Harrison, 1996). Many tasks that must be performed are unique and complex and thus require teams to possess a unique set of skills and knowledge (Waker, 2001). Most software projects in industry are accomplished by teams of professionals rather than

Material published as part of this publication, either on-line or in print, is copyrighted by the Informing Science Institute. Permission to make digital or paper copy of part or all of these works for personal or classroom use is granted without fee provided that the copies are not made or distributed for profit or commercial advantage AND that copies 1) bear this notice in full and 2) give the full citation on the first page. It is permissible to abstract these works so long as credit is given. To copy in all other cases or to republish or to post on a server or to redistribute to lists requires specific permission and payment of a fee. Contact Publisher@InformingScience.org to request redistribution permission. by individuals due to the size of these projects but also because teams tend to perform better than individuals (Brown \& Dobbie, 1999). Often technological issues receive most of the focus in an effort to improve IS project performance, while soft issues such as team dynamics receive little attention. The high failure rate of IS projects also provides an indication that the performance of IS team members is dependent on other 
members of the team and not on technical skills alone (De Marco \& Lister, 1999). Finding innovative ways of designing IS project development teams to improve teamwork could thus result in more effective teams and thus higher performance overall (Leonard \& Swap, 1999; Waker, 2001). Often organizations use one of many personality typing approaches to ensure diversity in team roles that may influence effectiveness and thus have a positive impact on task performance (Campion, Medsker \& Higgs, 1993).

The importance of teamwork in industry demands universities to better prepare students for real life projects. One of the main benefits of team projects in tertiary education is to provide students with a unique experience of the multiple and diverse disciplines that are characteristic of the daily life of an Information Technology / Information Systems (IT/IS) specialist in industry (Scott, 2004). In addition to technical skills students also develop soft skills, like mutual respect for other team members, presentation and communication (Brown \& Dobbie, 1999).

This paper explores the team selection structures and approaches as discussed in the literature in order to derive a sound base to support team selection from the perspective of the systems development group project course. Although students who have completed the course are of the opinion that the group project is one of their best and rewarding learning experiences - in over $90 \%$ of course evaluations students agreed very strongly that this was the case - during their undergraduate studies, it remains a demanding course with many deliverables and deadlines. Project teams should be supported and carefully monitored to ensure success. For this reason it is important to understand and investigate team effectiveness and the impact it has on performance. The paper will refer to the systems development group project as a group project, but the group of students working together on a specific project will be referred to as a team. The paper reports on the implementation of some of the guidelines for team effectiveness found in the literature, in the project course. Finally it highlights some limitations that currently exist, and proposes approaches and future research to address these limitations.

\section{Teams}

\section{Team Structuring and Selection}

DuBrin (2002) defines a group as "a collection of people who interact with one another, are working towards a common purpose, and perceive themselves to be a group". Katzenbach \& Smith (1993) go further and define a team as a group that has a high degree of commitment from its members to achieving its goals and given objectives.

Much debate exists around the effective structuring of teams in a work environment. Teams can be structured in a variety of ways, and many formal structures have been developed for different purposes. Five distinct structures suggested by Mankin, Cohen \& Bikson (1996) are shown below in Table 1.

Table 1: Team Structures (adapted from Mankin, Cohen \& Bikson, 1996)

\begin{tabular}{|l|l|l|}
\hline \multicolumn{1}{|c|}{ TEAM STRUCTURE } & \multicolumn{1}{|c|}{ USES } & CHARACTERISTICS \\
\hline Work Teams & $\begin{array}{l}\text { Designed to produce a specific } \\
\text { product }\end{array}$ & Relatively permanent \\
\hline Project Teams & Designed for once-off tasks & $\begin{array}{l}\text { Systems Development Pro- } \\
\text { jects }\end{array}$ \\
\hline Parallel Teams & $\begin{array}{l}\text { Designed to deal with organiza- } \\
\text { tional issues without affecting } \\
\text { structure. }\end{array}$ & Usually temporary. \\
\hline
\end{tabular}




\begin{tabular}{|l|l|l|}
\hline Management Teams & $\begin{array}{l}\text { Designed to guide the organiza- } \\
\text { tion towards its objectives. }\end{array}$ & Usually permanent \\
\hline Ad Hoc Network & $\begin{array}{l}\text { Used by people sharing similar } \\
\text { interests. }\end{array}$ & Usually an informal group \\
\hline
\end{tabular}

When deciding which structure to use for a team, the team morale, productivity and quality of product to be developed should also be taken into account (McLeod \& Smith, 2001). From Mankin et al.'s (1996) study it seems natural that the once off student projects would fall under the Project Team structure.

The project teams are further more encouraged to be self-managed to a large degree. The Work in America Institute defines a self-directed work team as a "small, semi-autonomous, interdependent group working towards shared goals, with [a] significant degree of cross training, and responsible for a relatively complete unit of work" (HR Focus, 2002, p. 18). DuBrin (2002), similarly, defines self-managed work teams as a "formally recognised group of employees ... responsible for an entire work process ... that delivers a product or service to an internal or external customer". DuBrin (2002) further explains that self-managed teams tend to be far more productive with a higher level of overall performance due to the feeling of "ownership" instilled in each team member. Various instruments have been developed to identify characteristics of individual members of a team and the implementation of these to improve the effectiveness of the team (Broucek \& Randell, 1996).

In IS, teams are an integral part of the systems development process, thus it is important to pay attention to the way teams are selected. There are various different approaches available to assist in the selection of team members and the forming of teams. These approaches include the MyersBriggs Type Indicator, Belbin's Team Role theory, random selection, students' selection and lecturer selection.

The Myers-Briggs Type Indicator uses a questionnaire to measure an individual's personality. This measurement of four personality types focuses on how individuals direct their energy, how they view or receive information, how they make decisions, and how they organize their environment (Gifford, Henry \& Schoenhof, 2003; Kaiser \& Bostrom, 1982; Mason \& Mitroff, 1973). The Myers-Briggs Type Indicator is regarded as a highly effective method of determining dominant personality traits within individuals. Research indicates that a team is likely to perform more effectively when it is formed by balancing the four Jungian personality types (Kaiser \& Bostrom, 1982).

R. Meredith Belbin developed a similar method that measures how an individual's personality tends to fill each of the different roles in a team (Belbin, 1981; Henry \& Stevens, 2002a, 2002b). This method helps to create balanced teams, which Gifford et al. (2003) believe potentially perform at a higher level. Belbin further argues that team members' sense of commitment grows stronger as they better understand their own roles within the team.

In a study by Henry (2000), it was found that personality testing is most effective when selecting members for student teams. Gifford et al. (2003) found that many student teams with similar skills and experience performed with varying levels of success. The lack of performance was believed to be a result of poor team development, which occurred due to the incompatibility of team members' personalities. This was a key finding as it showed that technical skills alone will not see a team performing well; the team selection and structure needs to be managed too. Gifford et al. (2003) state that it is not enough to simply place several highly skilled programmers and analysts together, but one must consider the "personality characteristics ... that advance or impair the team effort and ultimately the final outcome of the project team". There has been some research contradictory to Gifford et al. (2003), by Partington \& Harris (1999) who found that highly diverse teams did not necessarily perform better, and Winter (2004) who found little correlation 
between role diversity and performance in his study on team role diversity in student computer science teams.

The other team selection approaches include random selection, which can be seen as unfair by students and result in ineffective teams due to students being unhappy with the selection; student selection, which can result in some very strong teams and some very weak teams; and lecturer selection, which is difficult to do well due to the amount of work involved in the process.

Despite this debate on best practices to support the diverse nature of teams, Scott et al. (1994) state that no single selection method is the best and that the selection criteria depend on the specific course, the demands placed on students and lecturers, the length of the course and the ability of the students involved.

\section{The Impact of Team Effectiveness on Performance}

A core element in evaluating and measuring teams is effectiveness. The 1998 Advanced Learner's Oxford dictionary defines effectiveness as: "having the desired effect; producing the intended result... making a strong and pleasing impression". Gibson, Zellmer-Bruhn \& Schwab (2003) describe effectiveness as "the number of errors made". Thus, effectiveness can be defined as the product of clear goals and objectives whereby a pleasing impression has been created through competent labor, and where there has been a minimization of the number of errors made during the course of completing an objective. Further, effectiveness can also be understood as the team's ability to perform.

Belbin (2004) states that the effectiveness of a team is determined by the extent to which it "meets its goals, maintains the satisfaction of its members and survives". Cohen \& Bailey (1997) add that effectiveness also encompasses the quality of the final product and the degree of enjoyment the members had of the project experience. Campion et al. (1993) confirm this by stating that effectiveness incorporates three important criteria, namely: productivity, employee satisfaction and manager judgement. In using productivity as a measure of effectiveness Campion et al. (1993) refer to the collection and the regular monitoring of different measures as indicators of the amount of work completed. Therefore, it can be concluded that team effectiveness can be determined by:

- Enhanced productivity as a result of the increased levels of interaction between team members arising from teamwork

- The degree to which team members enjoy the project experience

- The quality of the final product produced by the team in achieving the desired goal

But just knowing what encompasses effective teams is not enough to achieve them; effective management is needed. This is echoed by Hackman (1987) who suggests that "many types of behavior can be productive; therefore, those who create and lead teams should focus on creating the right conditions for them to succeed, rather than trying to manage their behavior". Thus, creating the correct environment for teams is crucial in providing an atmosphere in which effective teamwork is possible.

In this study, team effectiveness is measured by an instrument adapted from a survey developed by Francis \& Young (1992), (see adapted questionnaire given in the Appendix). Through an extensive interviewing process Francis \& Young (1992) established the main characteristics of effective teams and concurred that "effective teamwork is the synthesis of apparently contrary forces". They explain that the effectiveness and well-being of teams should be assessed by the teams themselves and developed a team-review survey to examine 12 key aspects of a team's effectiveness. 


\section{The Experience}

\section{The Systems Development Group Project}

The third year systems development group project is the main deliverable of the capstone course of the IS major at the University of Cape Town. It has been developed and refined over a period of six years to integrate soft and hard skills. A comprehensive assessment strategy to enhance student learning and aid objective assessment of group performance forms an important component of this course (Scott \& Van Der Merwe, 2003). In addition to the initiation of the group projects and the completion of the analysis and design phases, the first half of the course is also dedicated to a more formal skills transfer approach. During this time lectures, project management workshops, practical programming sessions and sessions on group conflict resolution take place. The second half of the course is dedicated to the building of the product. The project starts in February and has its final hand-in date in September. The project comprises eight interim deliverables culminating into three milestone deliverables and the final product. The project teams are expected to adhere to strict deadlines to complete the regular deliverables in order to monitor the progress of the team and enhance the quality of the final product. During the lifecycle of the project, teams have the opportunity to improve interim deliverables before re-working them into related milestone deliverables. The final product, which includes extensive documentation and the corresponding software application, is showcased to the public at an exhibition event once the final assessment procedures are completed. For many students this project is a first experience of a major team project and it is essential to pay attention to factors that impact the effectiveness and overall performance of the teams.

The group project mainly uses the self-selection approach whereby students select their own teams. This selection approach does not compromise too much on team diversity as it seems that diverse groups can be formed naturally. When problems are encountered with this approach, such as a number of students being left without teams, the lecturer selection approach is used. The skills of these remaining students are assessed and the students are assigned to teams by the lecturer.

In 2005 each of the 25 teams completed a team contract that included statements on code of conduct, participation, communication, meeting guidelines and problem solving at the offset of the project; as recommended by Schwalbe (2003). Every year teams use a two week period to find a sponsor in industry with a business problem that best fits the generic project brief. Student teams may tender for existing projects, should there be any available. Each team chooses roles for each of its members, including a project leader, head programmer, head documenter, communications officer and quality controller and is also assigned a faculty member acting as a project manager.

\section{Instruments and Data Collection}

Questions in the Francis \& Young (1992) survey were posed initially to identify blockages that will inhibit the flow of energy and therefore hamper the performance of the teams. This survey was adapted to measure the effectiveness of the third year student project teams. For this purpose only nine of the question sections of the Francis \& Young survey were included from the original twelve aspects; the remaining three sections were either not relevant or were contained within the nine sections. Some questions pertaining explicitly to corporate institutions were omitted. Specific questions on technical skills were included under the Skills heading as students are still in the process of developing these skills. Although vital for the success of the project a high level of competency in these skills cannot always be assumed for all students. In an educational environment mentors play an important role and some questions under the heading Team Support were used to establish the impact of the support of project manager and the sponsor on the effective- 
ness of the team. Table 2 exhibits the mapping of 9 headings of the team effectiveness survey used in the third year project onto the 12 aspects of the Francis \& Young (1992) survey (see appendix for the questionnaire).

Table 2: Effectiveness measures mapped onto 12 aspects of Francis \& Young (1992)

\begin{tabular}{|l|l|}
\hline $\begin{array}{l}\text { HEADINGS OF ADAPTED QUESTION- } \\
\text { NAIRE }\end{array}$ & $\begin{array}{l}\text { ASPECTS OF FRANCIS \& YOUNG } \\
\text { QUESTIONNAIRE }\end{array}$ \\
\hline Clarity of roles, goals and objectives (CL) & $\begin{array}{l}\text { Role clarity; Team achievement; Relevant } \\
\text { corporate role }\end{array}$ \\
\hline Leadership (L) & Effective team leadership \\
\hline Competence (COMP) & Team achievement \\
\hline Commitment (CMT) & $\begin{array}{l}\text { Commitment; Positive climate; Team } \\
\text { achievement }\end{array}$ \\
\hline Communication (COMM) & Positive climate \\
\hline Skills (S) & Choosing the members of a team \\
\hline Team Support (TS) & Inter-team relationships \\
\hline Creativity (Cr) & Team creativity \\
\hline Achieving learning goals (ALG) & $\begin{array}{l}\text { Positive climate; Team achievement; Effec- } \\
\text { tive meetings }\end{array}$ \\
\hline
\end{tabular}

This paper reports on data collected from 123 students, represented by 24 project teams of 5 members each and one team with only 3 members (see Table 3 below). The student survey, course evaluations and Francis \& Young (1992) effectiveness questionnaire were sent to each individual student, while the six weekly update reports were sent to each group.

Table 3: Data collection instruments responses

\begin{tabular}{|l|l|l|l|l|}
\hline INSTRUMENT & WHEN & SENT & RESPONSES & $\mathbf{\%}$ \\
\hline Student survey & April & 123 & 123 & $100 \%$ \\
\hline Course evaluation 1 & May & 123 & 75 & $61 \%$ \\
\hline Course evaluation 2 & September & 123 & 112 & $91 \%$ \\
\hline $\begin{array}{l}\text { 6 x Weekly team up- } \\
\text { date reports }\end{array}$ & July - August & 150 & 126 & $84 \%$ \\
\hline $\begin{array}{l}\text { Francis \& Young ef- } \\
\text { fectiveness question- } \\
\text { naire }\end{array}$ & October & 123 & 34 & $28 \%$ \\
\hline Performance results & April - October & 123 & 123 & $100 \%$ \\
\hline
\end{tabular}

To measure performance, marks composed of all the deliverables and assessment opportunities from the course were used (see Table 4). 
Table 4: Assessment opportunities (adapted from Scott \& van der Merwe, 2003)

\begin{tabular}{|l|l|l|l|}
\hline COMPONENT & OCCURRENCE & $\begin{array}{l}\text { GROUP / IN- } \\
\text { DIVIDUAL }\end{array}$ & $\begin{array}{l}\text { CONTRIBUTE TO } \\
\text { FINAL MARK }\end{array}$ \\
\hline Interim deliverables & $\begin{array}{l}8- \\
\text { approx every 2 weeks }\end{array}$ & Group & Yes \\
\hline Milestone deliverables & $\begin{array}{l}3- \\
\text { approx every 6 weeks }\end{array}$ & Group & Yes \\
\hline Weekly reports & Weekly & Group & No \\
\hline $\begin{array}{l}\text { Weekly project manage- } \\
\text { ment meeting }\end{array}$ & Bi-weekly & Group & No \\
\hline Sponsor meetings & When required & Group & No \\
\hline Sponsor evaluations & Twice & Group & Yes \\
\hline Course evaluation & Twice & Individual & No \\
\hline Peer and self evaluations & $\begin{array}{l}\text { When required and once } \\
\text { as part of final assess- } \\
\text { ment }\end{array}$ & $\begin{array}{l}\text { Individual and } \\
\text { Group }\end{array}$ & $\begin{array}{l}\text { Yes } \\
\text { (Final assessment) }\end{array}$ \\
\hline Weekly Update reports & $\begin{array}{l}\text { 6 - } \\
\text { from July to August }\end{array}$ & Group & No \\
\hline Final presentation & Once & Group & Yes \\
\hline Code review & Once & Yroup \\
\hline
\end{tabular}

\section{Team Effectiveness}

\section{The Composition of Semi Self-Selected Teams}

Although teams are mostly self-selected a faculty member in the department of Industrial Psychology facilitates and finalizes the team formation process. Student surveys filled out prior to the team selection process are used to assist the facilitator. In these surveys students are mainly required to list their strengths, weaknesses, skills and what they intend to contribute to the project and the team. The survey requires each respondent to rate him/herself on a scale from 1 to 10 (10 being best) on each of the following skills: Real Project Experience (RPE); Customer Interaction (CI); Research Skills (RS); Writing Skills (WS); Presentation Skills (PS); Programming Skills (PRGS); Project Management Software (PMS); Website Creation (WC) Leadership (L); Teamwork Facilitation (TF).

The data on each individual survey was captured and then grouped into the different teams. For every team all ratings greater than 6 (7 and more) in each skill category were counted to provide an indication of the diversity and competence of a team. Twelve teams indicated that they had one or more members per skills category with a rating above 6 . The numbers in Table 5 indicate how many teams had no members with a rating of 7 or more for a specific skills category.

Five teams indicated that they lacked real project experience (RPE). This can be justified as the group project is a first encounter of a real life project for most of the teams. The lack in programming (PRGS), project management software (PMS) and web creations (WC) skills were ad- 
dressed during the first half of the course by means of lectures, workshops and practical programming sessions. To empower students with advanced programming skills, a carefully guided pilot system was developed over eight programming sessions. Students obtained web development skills in a parallel e-Commerce course. Although the teams showed some diversity of the skills and experience that they had, the teams were generally on a balanced playing-field.

Table 5: The number of teams lacking skills in a specific skills category

\begin{tabular}{|c|l|l|l|l|c|c|c|c|c|}
\hline RPE & CI & RS & WS & PS & PRGS & PMS & WC & L & TF \\
\hline 5 & 0 & 0 & 1 & 1 & 4 & 7 & 9 & 0 & 0 \\
\hline
\end{tabular}

In order to gain insight into the effectiveness of each team involved in the study, a selfassessment survey was distributed to each member of that team. The survey focused on the core criteria, which according to Francis \& Young (1992) contribute to an effective team. The team's level of effectiveness was then assessed by calculating their mean scores from the questionnaires. A high mean indicates that the team is highly effective, while a low mean indicates inherent weaknesses.

From the effectiveness questionnaire it was found that the leadership section had the highest mean across teams, with a mean of $82 \%$, while the section on creativity followed some distance behind with a mean across teams of $64 \%$. The section with the lowest mean across teams was found to be achieving learning goals with a mean of $42 \%$. The means across teams for all of the sections can be seen in Table 6 below.

Table 6: Effectiveness means across teams

\begin{tabular}{|c|c|c|c|c|c|c|c|c|}
\hline CL & L & COMP & CMT & COMM & S & TS & Cr & ALG \\
\hline $56 \%$ & $82 \%$ & $45 \%$ & $52 \%$ & $56 \%$ & $58 \%$ & $47 \%$ & $64 \%$ & $42 \%$ \\
\hline
\end{tabular}

\section{Enhanced Productivity and Increased Levels of Interaction between Team Members}

Campion et al. (1993) associated productivity measures with amount of work finished on a weekly basis. The third year group project uses an assessment strategy as depicted in Table 4 to assist students to complete tasks and deliverables on time and enhance productivity. The opportunity to improve interim deliverables before submitting them as milestone deliverables simultaneously enhances the quality of the product.

In addition to assessment opportunities several mechanisms are implemented throughout the course to make teams productive. Once a team has identified a sponsor and the related documents specifying the terms of reference and responsibilities are completed, students set up regular meetings with sponsors to understand the business problem and obtain the user requirements. It is required that they conduct regular team meetings and also meet with their respective project managers on a weekly or bi-weekly basis. Weekly reports are used to keep track of these meetings, reporting on new ideas, problems and resolutions. Microsoft (MS) Project Server 2003 is used with Microsoft Project 2003 to develop the individual project plans and to provide a secure environment for each team. Through its MS Project Web Access Interface, MS Project Server enables team members and stakeholders to collaborate, get access to project related documents and keep their project plans updated.

During the build phase, at least one representative of each team attends weekly class meetings and submits a weekly update report. All the teams except one, Tri-Communications, attended the 
meetings. Tri-Communications was the only team with less than 5 members, it had 3; but they appeared to be on track with their project as they obtained a 66\% final project result. Advanced topics that might assist the building phase are also discussed. In 2005 each team had 6 opportunities to submit these reports that served as a "wellness" check and provided valuable information on the effectiveness and current performance of the respective teams. Teams reported on resolved and unresolved issues. They also indicated whether they were on target to finish the project within schedule, and whether they had team, project manager or sponsor problems. In those cases where problems existed, immediate action was taken after the meeting. Table 7 shows whether the teams were on target to finish the project within schedule during the build phase.

From the weekly update reports it was also found that 5 of the teams had consistent internal problems with team members. Three of these teams did not resolve these problems by the end of the project and team members were negatively affected by peer evaluations, which subtract marks from students who were judged by their fellow team members not to have performed adequately.

Table 7: Number of teams on target through the project build phase

\begin{tabular}{|c|l|}
\hline NUMBER OF TEAMS & ON TARGET? \\
\hline 4 & Yes \\
\hline 9 & No \\
\hline 1 & No, then Yes \\
\hline 3 & Yes, then No \\
\hline 7 & Combination of Yes and No \\
\hline 1 & Didn't attend \\
\hline
\end{tabular}

\section{The Team Members' Enjoyment of the Project Experience}

A controlled and well-managed environment is necessary to create a safe space for creative development of project teams. A positive atmosphere is furthermore conducive to the productivity of teams, encourages enjoyment of the project experience, motivates teams to commit and achieve their goals.

At the end of the first and second halves of the course a course evaluation was conducted. Each student was handed an evaluation questionnaire to be completed individually. In Table 8 below, some of the questions that relate to the paper and their responses are listed. The questionnaire made use of a 6 point Likert scale, which is standardized across the department. The response percentages listed in Table 8 below indicate the percentage of students that answered the questions with the top two Likert scales, i.e. excellent and very good. In other words, the percentage of students that agreed most strongly with the statements in the questionnaires.

Table 8: Course evaluation responses

\begin{tabular}{|l|l|l|}
\hline QUESTION & $\begin{array}{l}\text { EVALUATION 1 } \\
\text { RESPONSES }\end{array}$ & $\begin{array}{l}\text { EVALUATION 2 } \\
\text { RESPONSES }\end{array}$ \\
\hline Usefulness of the project as a learning experience & $91 \%$ & $90 \%$ \\
\hline Preparation for the IS profession & $69 \%$ & $66 \%$ \\
\hline People and communication skills required & $75 \%$ & $62 \%$ \\
\hline
\end{tabular}




\begin{tabular}{|l|l|l|}
\hline $\begin{array}{l}\text { Experience gained in handling project management } \\
\text { issues }\end{array}$ & $75 \%$ & $68 \%$ \\
\hline $\begin{array}{l}\text { Effectiveness of course communication with regards } \\
\text { to resolving project related issues }\end{array}$ & $73 \%$ & $53 \%$ \\
\hline
\end{tabular}

Numerous comments in the course evaluations indicated that despite the huge challenge of the project, students were highly motivated and committed and thoroughly enjoyed the experience. Many commented that the most positive aspect of the course was the learning experience with regard to communication with the sponsor, systems development, group conflict and work attitudes. The responses in Table 8 also reflect these opinions.

\section{Quality of the Final Product Produced}

In Figure 1 below it can be seen that all of the teams passed the project, scored above 50\%, except for Logix Solutions, which scored 47\%. 13 teams, over half of the total teams, scored above $65 \%$ for the project which points towards a high level of overall quality of the 2005 projects.

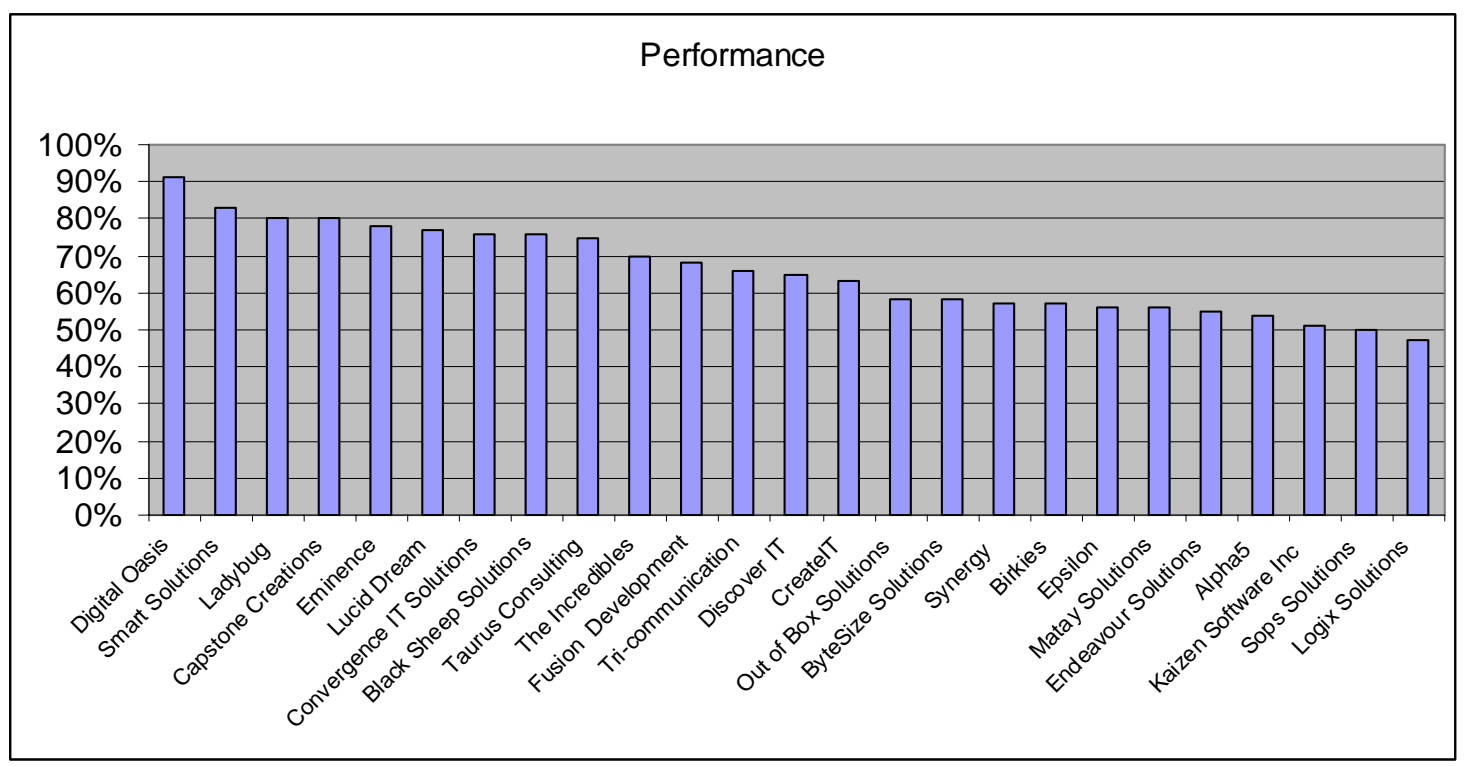

Figure 1: Final project results for each team

Sunstrom, De Meuse \& Futrell, (1990) concur that one of the aspects of effectiveness is performance and therefore performance has a direct relationship to effectiveness (Katzenbach \& Smith, 1992). To determine why the teams performed well and produced quality projects, the performance data was analyzed with the effectiveness data.

A correlation analysis between performance, taken from the final project result scored by each team, and the elements of effectiveness, from the Francis \& Young (1992) questionnaire, revealed the strongest correlations to be between performance and competence being 0.68 , followed by performance and skills with a score of 0.58 , performance and creativity with 0.55 , and performance and commitment with 0.52 . This correlation matrix can be seen in Figure 2 below, where correlations below 0.5 can be disregarded as insignificant (Keller \& Warrack, 2003). 


\begin{tabular}{|c|c|c|c|c|c|c|c|c|c|c|}
\hline & $\begin{array}{c}\text { Claity Or Roles, } \\
\text { Goals and } \\
\text { Obiestimes }\end{array}$ & Lesderstip & Competence & Commitmert & Cemenuricution & Shils & $\begin{array}{l}\text { Team } \\
\text { Suppon }\end{array}$ & Crestivty & $\begin{array}{c}\text { Acchiming } \\
\text { Lesming } \\
\text { Goals }\end{array}$ & Pesomance \\
\hline $\begin{array}{l}\text { Clant y CRRsies, Geals } \\
\text { und Cojitetenss }\end{array}$ & 100 & 0.18 & 0.10 & 0.10 & 0.37 & 0.12 & .0 .06 & 0.17 & 0.48 & 0.08 \\
\hline Lesdership & 0.18 & 100 & -0.00 & 0.05 & 0.01 & 0.37 & 0.06 & 0.15 & 033 & 0.31 \\
\hline Comperence & 0.10 & -0.03 & 100 & 098 & 0,07 & -0.51 & 0.24 & -071 & 0.32 & -068 \\
\hline Commement & 0.10 & 0.06 & 0.92 & 100 & 0.01 & 0.36 & 0.29 & 0.74 & 0.45 & 0.52 \\
\hline Communiction & 0.37 & 001 & 0.07 & -0.01 & 100 & -0.07 & 0.21 & -0.01 & 0.09 & 0.12 \\
\hline Sxills & 0.12 & .0 .37 & -0.51 & .0 .36 & 0.07 & 100 & 0.07 & 0.44 & 004 & 0,58 \\
\hline Tesm Supgon & 006 & -006 & 0.24 & 0.29 & 021 & -0.07 & 100 & -0.63 & 001 & 0.19 \\
\hline Censevaty & 0.17 & -0.15 & -0.71 & -074 & 001 & 0.4 & -0.63 & 100 & 023 & 0.55 \\
\hline Achieving Leaming Goals & 0.48 & 0.30 & 0.32 & 0.46 & 0.09 & 0.04 & 0.01 & .0 .23 & 100 & 0.27 \\
\hline Performance & 0.00 & .0 .31 & -0.68 & .0 .52 & 0.12 & 0.58 & 0.19 & 0.55 & 0.27 & 100 \\
\hline
\end{tabular}

Figure 2: Correlation matrix of performance and elements of effectiveness

Of the fifteen teams that answered the effectiveness questionnaire, it can be seen in Figure 3 below that Epsilon rated itself that most effective, followed by Kaizen Software Inc. and Fusion Development. Birkies rated itself the least effective. Figure 3 below illustrates that there is no clear correlation between effectiveness, taken as a whole from all of the sections of the Francis \& Young (1992) effectiveness questionnaire, and performance, taken as the final project result. While it does appear that the weaker teams rate themselves as highly effective, as in the cases of Epsilon, Kaizen Software Inc. and, to a lesser extent, Endeavour Solutions, this is not always the case, as can be seen by the teams of Out Of Box Solutions and Birkies. The teams that performed the best, i.e. the top six teams that answered the questionnaires, all rated themselves as having moderate to low effectiveness, i.e. within the lower half of the effectiveness rankings. These teams include Smart Solutions, Ladybug, Capstone Creations, Eminence, Black Sheep Solutions and Convergence IT Solutions.

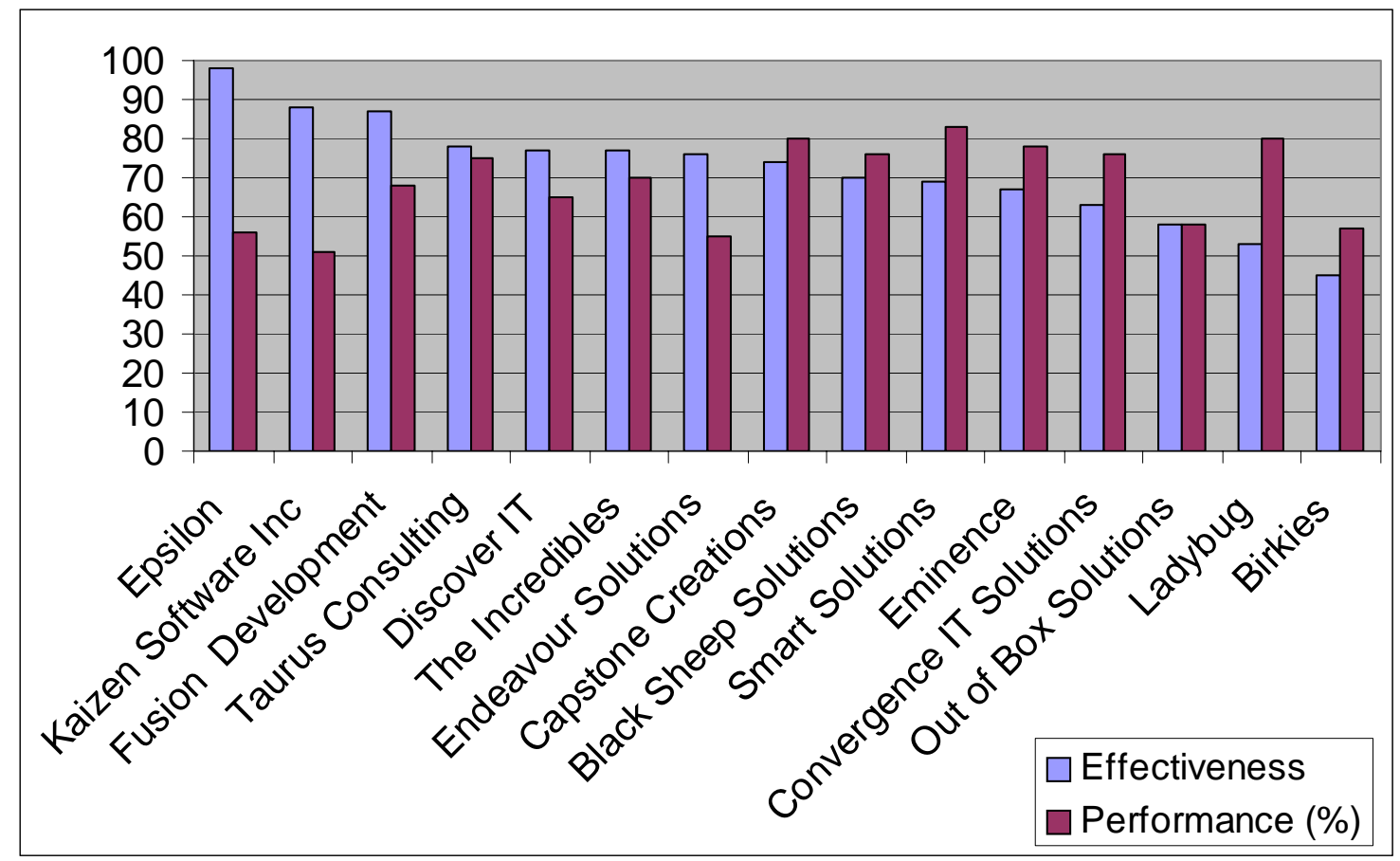

Figure 3: Effectiveness versus performance

From the data collected there is no indication as to why this occurs. But it could be that the weaker teams have unrealistic perceptions of their own abilities and tend to be over-optimistic 
about how well they work and the quality of their work. Stronger teams may be more restrained about their perceptions of their ability to work and their quality of work. This may lead to an overly pessimistic view of their abilities and thus a lower self-rating of their effectiveness.

\section{Conclusion}

The research presented in this paper has confirmed that the systems development group project creates a positive learning environment, provides a real-world experience and prepares students effectively for the rigours of industry.

Although there is merit in using the different approaches available to assist in the selection of teams, this paper has shown that self-selected team can be effective and that despite of team being self-selected a diverse range of skills were present in all the teams. The facilitation process during team formation has proved to be valuable and helped to complete the process timeously and efficiently.

Several sources in the literature agreed that team morale, productivity and the quality of the product to be developed are important elements of team work. These elements are represented in effectiveness criteria as defined by Campion et al. (1993) and were used to gauge the effectiveness of the student teams. A controlled and well-managed environment with regular assessment opportunities and reporting mechanisms encouraged increased levels of interactions between team members and enhanced the productivity of the teams. Despite the demanding nature of the group project the students coped with and enjoyed the challenges they were confronted with. The good performance of the teams overall and the quality of the final products led to a high level of effectiveness in the self-selected project teams. The students described the project experience with the keywords: vision, commitment and excellence.

This study opens the door for future research on teams with effectiveness, performance, role diversity and different selection approaches as key features.

\section{References}

Belbin, R.M. (1981). Management teams: Why they succeed or fail. Butterworth-Heinemann, Oxford.

Belbin, R.M. (2004). Belbin Team Roles. Belbin Home Page. Retrieved April 16, 2004 from http://www.belbin.com/belbin-team-roles.htm

Broucek, W.G. \& Randell, G. (1996). An Assessment of the construct validity of the Belbin SelfPerception Inventory and Observer's Assessment from the perspective of the five-factor model. Journal of Occupational and Organizational Psychology, 69, 389-405.

Brown, J.\& Dobbie, G. (1999). Supporting and evaluating team dynamic in group projects, ACM SIGCSE Bulletin, 31(1), 281-285.

Campion, M.A, Medsker, G.J. \& Higgs, C.A. (1993). Relationships between work group characteristics and effectiveness: implications for designing effective work groups, Personnel Psychology, 46, 823-843.

Cohen, S.G. \& Bailey, D.E. (1997). What makes teams work: group effectiveness research from the shop floor to the executive suite, Journal of Management, 23 (3), 239-290.

DeMarco, T. \& Lister, T. (1999). Peopleware, productive projects and teams. $2^{\text {nd }}$ Ed., Dorset House Publishing Corporation Inc., New York.

DuBrin, A.J. (2002). '1-15’ in Fundamentals of Organizational Behavior, eds. Szilagyi, J., South-Western College Publishing, United States of America, 1-372.

Five Case Studies on Successful Teams. (2002). HR Focus , 79 (4), 18-19. 
Francis, D. \& Young, D. (1992). Improving work groups: A practical manual for team building. Pfeiffer \& Co.

Gerstmann, P. (2004). Team roles: Individual \& group effectiveness - FIRO Team Roles and Belbin TeamRoles contrasted. Retrieved November 7, 2005 from http://www.pgagroup.com/team-roles.cfm

Gibson, C.B., Zellmer-Bruhn, M.E. \& Schwab, D.P. (2003). Team effectiveness across contexts, Group \& Organizational Management, 28 (4), 444-474.

Gifford, S.S, Henry, S.M. \& Schoenhof, P.K. (2003). Personality type considerations for programming teams in computer science classes. Retrieved April 16, 2004 from http://csgrad.cs.vt.edu/ sgifford/research/ptcpt.pdf

Hackman, J.R. (1987). The design of work teams, Handbook of Organizational Behaviour. Englewood Cliffs, NJ: Prentice Hall, 315-342.

Henry, S. (2000). Using software development teams in a classroom environment, EBSCO Online Journal.

Henry, S.M. \& Stevens, K.T. (2002a). Analyzing software teams using Belbin’s Innovative Plant Role. Retrieved November 7, 2005 from http://www.radford.edu/ kstevens2/ISTall.pdf

Henry, S.M. \& Stevens, K.T. (2002b). Using Belbin's Leadership Role to improve team effectiveness. Retrieved November 7, 2005 from http://courses.cs.vt.edu/ cs4704/jss.pdf

Jones, M.C. \& Harrison, H.W. (1996). Project team performance: An empirical assessment, Information and Management, 13, 57-65.

Kaiser, K.M. \& Bostrom, R.P. (1982). Personality characteristics of MIS project teams: An empirical study and action-research design, MIS Quarterly, December 1982, 43-60.

Katzenbach, J.R. \& Smith, D.K. (1992). Why teams matter, McKinsey Quarterly, 3, 3-27.

Katzenbach, J.R. \& Smith, D.K. (1993). The discipline of teams, Harvard Business Review, 71 (2), 111120.

Keller, G. \& Warrack, B. (2003). Statistics for management and economics, Brooks/Cole, Division of Thomson Learning Inc., U.S.A.

Leonard D.A. \& Swap W.C., (1999). When sparks fly - Igniting creativity in groups. Harvard Business School Press, Boston.

Mankin, D., Cohen, S.G. \& Bikson, T.K. (1996). Teams and technology: Fulfilling the promise of a new organization. Boston, MA: Harvard Business School Press.

Mason, R. \& Mitroff, I. (1973). A program of research on MIS, Management Science, 19 (5), 475-485.

McCloed, G. \& Smith, D. (2001). Managing Information Technology projects. eds. Edwards, J, Inspired Press, South Africa.

Partington, D. \& Harris, H. (1999). Team role balance and team performance: an empirical study, Journal of Management Development, 18 (7/8), 694-705.

Schwalbe, C. (2003). Information Technology project management, Course Technology; 3rd Bk\&Cdr.

Scott, E.C. (2004). Systems development group project: A real world experience, Proceedings of the Information Systems Education Conference, Newport, Rhode Island, USA.

Scott, E.C. \& Van Der Merwe, N. (2003). Using multiple assessment approaches to enhance objectivity and student learning. A special conference edition of the Electronic Journal of Information Systems Evaluation, 6 (2), 182-186.

Scott, T.J., Tichenor, L.H., Bisland, R.B. \& Cross, J.H. (1994). Team dynamics in student programming projects, ACM SIGCSE Bulletin, 26 (1), 111-115.

Sundstrom, E., De Meuse, K.P. \& Futrell, D. (1990). Work teams, American Psychologist, Feb 1990, 120 133. 
Waker, L. (2001). Enhancing Information Systems project team performance: Team member selection strategies, Masters Dissertation, Department of Information Systems. University of Cape Town, Cape Town, South Africa.

Winter, M. (2004). Developing a group model for student software engineering teams, Graduate Studies and Research, Department of Computer Science, University of Saskatchewan, Saskatoon.

Wynekoop, J.L. \& Walz, D.B. (1998). Revising the perennial question: Are IS people different?, The DATA BASE for Advances in Information Systems, 29 (2), 62-72.

\section{Appendix}

\section{Modelling Effective IS Teams \\ Francis \& Young (1992) Team Effectiveness Survey}

Team Name

Please indicate:

\begin{tabular}{|l|l}
\hline & Team Member \\
Team Leader
\end{tabular}

Please consider each of the following statements in relation to your systems development project teams and answer to the best of your knowledge. The accuracy of this survey depends on your openness and honesty in answering the questions

Please indicate your level of agreement (by highlighting in RED, as shown) with the following statements,

\begin{tabular}{|c|c|c|c|c|}
\hline $\mathbf{1}$ & $\mathbf{4}$ & $\mathbf{3}$ & $\mathbf{4}$ & $\mathbf{5}$ \\
\hline Agree & Agree Somewhat & Neutral & $\begin{array}{c}\text { Disagree } \\
\text { Somewhat }\end{array}$ & Disagree \\
\hline
\end{tabular}

1

SECTION A: CLARITY of Roles, Goals, and Objectives

\begin{tabular}{|c|c|c|c|c|c|}
\hline Team roles are clearly defined & 1 & 2 & 3 & 4 & 5 \\
\hline Team members are clear about goals & 1 & 2 & 3 & 4 & 5 \\
\hline Leadership is clear and unambiguous & 1 & 2 & 3 & 4 & 5 \\
\hline We are clear about how individual and team performance will be measured & 1 & 2 & 3 & 4 & 5 \\
\hline The objectives of some team memebers conflict with others & 1 & 2 & 3 & 4 & 5 \\
\hline Members of the team do not fully understand one anothers roles & 1 & 2 & 3 & 4 & 5 \\
\hline Team members are uncertain about their individual roles in relation to the team & 1 & 2 & 3 & 4 & 5 \\
\hline I could not, with complete confidence, define my own role within the team & 1 & 2 & 3 & 4 & 5 \\
\hline
\end{tabular}

2

SECTION B: LEADERSHIP

The leader and team members spend little time clarifying what they expect and need from one another

The leader rarely tolerated leadership efforts by other team members

The leader gives his or her own view before other members of the team have contributed

their views 


\begin{tabular}{|l|l|l|l|l|l|}
\hline The leader does not welcome feedback about how the team sees his/her performance & $\mathbf{1}$ & $\mathbf{2}$ & $\mathbf{3}$ & $\mathbf{4}$ & $\mathbf{5}$ \\
\hline The team leader makes decisions without talking them over with the team members & $\mathbf{1}$ & $\mathbf{2}$ & $\mathbf{3}$ & $\mathbf{4}$ & $\mathbf{5}$ \\
\hline The leader is not willing to have his or her ideas challenged & $\mathbf{1}$ & $\mathbf{2}$ & $\mathbf{3}$ & $\mathbf{4}$ & $\mathbf{5}$ \\
\hline
\end{tabular}

\begin{tabular}{|c|c|c|c|c|c|}
\hline We often achieve our goals & 1 & 2 & 3 & 4 & 5 \\
\hline Rate the team members' skills and abilities in being able to carry out their tasks & 1 & 2 & 3 & 4 & 5 \\
\hline We use resources effectively & 1 & 2 & 3 & 4 & 5 \\
\hline Our team has a good balance and mix of skills, abilities and personalities & 1 & 2 & 3 & 4 & 5 \\
\hline Correct people, with the correct skills are assigned to the correct tasks & 1 & 2 & 3 & 4 & 5 \\
\hline Does the team experiment with untried ideas that may have potential benefits? & 1 & 2 & 3 & 4 & 5 \\
\hline Does the team utilise individuals' experience and integrate it with team knowledge? & 1 & 2 & 3 & 4 & 5 \\
\hline Does the team have a healthy self-belief in themselves and their team identity? & 1 & 2 & 3 & 4 & 5 \\
\hline
\end{tabular}

\section{4}

SECTION D: COMMITMENT

\begin{tabular}{|c|c|c|c|c|c|}
\hline We are highly committed to the team's objectives & 1 & 2 & 3 & 4 & 5 \\
\hline We always fulfil our objectives & 1 & 2 & 3 & 4 & 5 \\
\hline We always fulfil our objectives on time & 1 & 2 & 3 & 4 & 5 \\
\hline Support for members within the team is strong & 1 & 2 & 3 & 4 & 5 \\
\hline Energy is used to solve problems rather than competitive struggles & 1 & 2 & 3 & 4 & 5 \\
\hline Conflict is discussed openly and managed constructively & 1 & 2 & 3 & 4 & 5 \\
\hline Participation a team responsibility & 1 & 2 & 3 & 4 & 5 \\
\hline Team members count on one another & 1 & 2 & 3 & 4 & 5 \\
\hline We are continuously improving group interaction and performance & 1 & 2 & 3 & 4 & 5 \\
\hline We often celebrate successes & 1 & 2 & 3 & 4 & 5 \\
\hline We often achieve collective goals or tasks through a concentrated action & 1 & 2 & 3 & 4 & 5 \\
\hline I am proud to be a member of my team & 1 & 2 & 3 & 4 & 5 \\
\hline I feel supported by the rest of the team & 1 & 2 & 3 & 4 & 5 \\
\hline Our team lacks a sense of energy an excitement & 1 & 2 & 3 & 4 & 5 \\
\hline We often fail to finish things in a satisfactory manner & 1 & 2 & 3 & 4 & 5 \\
\hline Some of the team members feel that the aims of the team are hardly worthwhile & 1 & 2 & 3 & 4 & 5 \\
\hline I do not feel a strong sense of belonging to this team & 1 & 2 & 3 & 4 & 5 \\
\hline
\end{tabular}

\begin{tabular}{|c|c|c|c|c|c|}
\hline Communication open and honest & 1 & 2 & 3 & 4 & 5 \\
\hline We use effective methods to communicate within and outside of formal team meetings & 1 & 2 & 3 & 4 & 5 \\
\hline Our team leader always keeps us informed of the latest developments & 1 & 2 & 3 & 4 & 5 \\
\hline Team performance is reviewed regularly & 1 & 2 & 3 & 4 & 5 \\
\hline Team meetings are highly focused & 1 & 2 & 3 & 4 & 5 \\
\hline Attempts to critically review events are negative to progress & 1 & 2 & 3 & 4 & 5 \\
\hline I am weary of suggesting new ideas & 1 & 2 & 3 & 4 & 5 \\
\hline Members restrain their critical remarks to avoid rocking the boat & 1 & 2 & 3 & 4 & 5 \\
\hline Team meetings lack a methodical approach & 1 & 2 & 3 & 4 & 5 \\
\hline Our meetings do not resolve all of the issues that should be addressed & 1 & 2 & 3 & 4 & 5 \\
\hline Performance would improve if constructive critism were encouraged & 1 & 2 & 3 & 4 & 5 \\
\hline People in this team sometimes do not say what they really feel & 1 & 2 & 3 & 4 & 5 \\
\hline
\end{tabular}


6 SECTION F: SKILLS

Please rate your ability regarding the following programming languages and skills where:

1 - Little or no knowledge

5 - Highly proficient and knowledgeable

Visual Basic.Net

ASP.Net

JavaScript

Php

HTML

UML and documentation

Systems analysis and design

Graphic design

\begin{tabular}{|l|l|l|l|l|}
\hline 1 & 2 & 3 & 4 & 5 \\
\hline 1 & 2 & 3 & 4 & 5 \\
\hline 1 & 2 & 3 & 4 & 5 \\
\hline 1 & 2 & 3 & 4 & 5 \\
\hline 1 & 2 & 3 & 4 & 5 \\
\hline 1 & 2 & 3 & 4 & 5 \\
\hline 1 & 2 & 3 & 4 & 5 \\
\hline 1 & 2 & 3 & 4 & 5 \\
\hline
\end{tabular}

\begin{tabular}{|c|c|c|c|c|c|}
\hline $\mathrm{v}$ of the & 1 & 2 & 3 & 4 & 5 \\
\hline Some team members may be unable to handle the current requiremen & 1 & 2 & 3 & 4 & 5 \\
\hline Our mix of skills is inappropriate for the work that we are doing & 1 & 2 & 3 & 4 & 5 \\
\hline We need an infusion of new knowledge and skills to make our team complete & 1 & 2 & 3 & 4 & 5 \\
\hline We lack the skills to review our effectiveness constructively & 1 & 2 & 3 & 4 & 5 \\
\hline We have the necessary skills to develop our project and achi & 1 & 2 & 3 & 4 & 5 \\
\hline
\end{tabular}

7

\section{SECTION G: TEAM SUPPORT}

\begin{tabular}{|l|l|l|l|l|l|}
\hline We have all the necessary information and technology available to us & $\mathbf{1}$ & $\mathbf{2}$ & $\mathbf{3}$ & $\mathbf{4}$ & $\mathbf{5}$ \\
\hline Our environment is conducive to productive working conditions & $\mathbf{1}$ & $\mathbf{2}$ & $\mathbf{3}$ & $\mathbf{4}$ & $\mathbf{5}$ \\
\hline Our project manager is highly supportive and knowledgeable & $\mathbf{1}$ & $\mathbf{2}$ & $\mathbf{3}$ & $\mathbf{4}$ & $\mathbf{5}$ \\
\hline Our sponsor is highly supportive & $\mathbf{1}$ & $\mathbf{2}$ & $\mathbf{3}$ & $\mathbf{4}$ & $\mathbf{5}$ \\
\hline Our sponsor is clear about his/her requirements & $\mathbf{1}$ & $\mathbf{2}$ & $\mathbf{3}$ & $\mathbf{4}$ & $\mathbf{5}$ \\
\hline We meet with our sponsor regularly (i.e every 2 - 3 weeks) & $\mathbf{1}$ & $\mathbf{2}$ & $\mathbf{3}$ & $\mathbf{4}$ & $\mathbf{5}$ \\
\hline Team members sometimes put down others in the team & $\mathbf{1}$ & $\mathbf{2}$ & $\mathbf{3}$ & $\mathbf{4}$ & $\mathbf{5}$ \\
\hline
\end{tabular}

8

SECTION H: CREATIVITY

\begin{tabular}{|c|c|c|c|c|c|}
\hline Not many new ideas are generated by the team & 1 & 2 & 3 & 4 & 5 \\
\hline Team members are weary about suggesting new ideas & 1 & 2 & 3 & 4 & 5 \\
\hline Good ideas seem to get lost & 1 & 2 & 3 & 4 & 5 \\
\hline The team needs the stimulus of more radical and creative people & 1 & 2 & 3 & 4 & $\mathbf{5}$ \\
\hline Creative ideas often are not followed up with definite action & 1 & 2 & 3 & 4 & 5 \\
\hline
\end{tabular}

9

SECTION I: ACHIEVING LEARNING GOALS

Excellent quality of work for each group member on individual projects

Excellent quality of work for group projects

Unanimous understanding and mastery: Everyone's learning is the priority: When someone is having difficulty, the group will provide extra time and support until material is master

OR

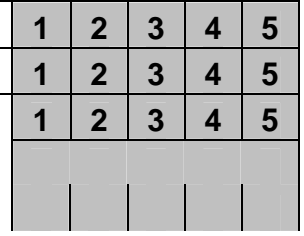


Each person is on his/her own. Group has only so much time. Only group tasks should addressed in group meetings. They should be achieved in the quickest and most expedient way (i.e. the most skilled person does what s/he does best and the others need not

Addressing learning needs and gaining in-depth understanding and ability to apply concepts and strategies learned

Improving interpersonal styles of communication. Involves asking for feedback on how well we express ourselves and interact in the small group setting

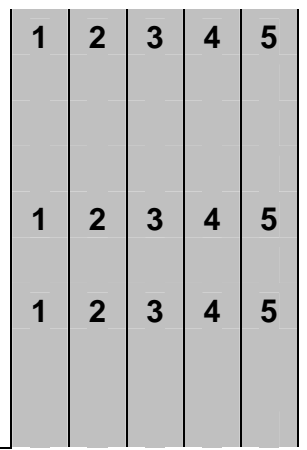

\section{Biographies}

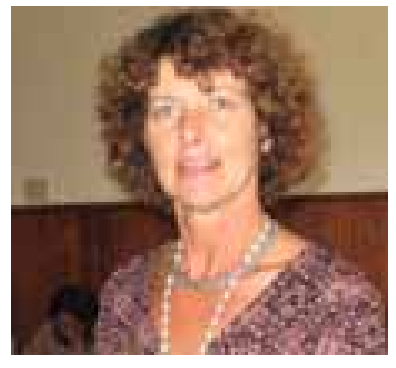

Elsje Scott is a Senior Lecturer in the Department of Information Systems at the University of Cape Town and has 21 years experience in teaching computer programming at tertiary institutions.

The author's main research interest is systems development group projects which involve knowledge areas like project management, people management and software engineering. Specific focus areas are software testing, object-oriented programming concepts, general issues concerning the development of efficient computer systems in Information Systems and assessment strategies and software standards. Other interests are Discrete Mathematics, with a specific interest in Graph Theory and the applications thereof.

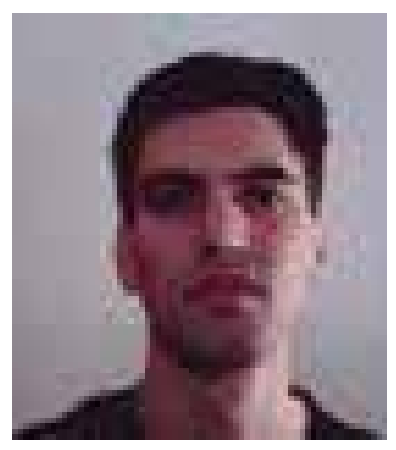

Michael Pollock is an assistant lecturer in the Information Systems Deptartment at UCT, and has worked in the department for 3 years. He has a BCOM (Hons) and MCOM in Information Systems from UCT. His research interests include technology adoption, IS project evaluation and IS teams. 